Resumo de Tese

\title{
Medida do volume do cerebelo fetal por meio da ultra-sonografia tridimensional
}

\section{Measurement of the fetal cerebellum volume through tridimentional ultrasonography}

Autor: Edward Araujo Júnior

Orientador: Prof. Dr. Antonio Fernandes Moron

Co-orientador: Prof. Dr. Cláudio Rodrigues Pires

Dissertação de Mestrado apresentada ao Departamento de Obstetrícia da Universidade Federal de São Paulo Escola Paulista de Medicina (UNIFESP/EPM), em 13 de março de 2006.

Objetivo: construir intervalos de referência do volume do cerebelo fetal por meio da ultra-sonografia tridimensional ao longo da gestação, avaliar a correlação do volume cerebelar fetal com parâmetros do crescimento fetal e testar a variabilidade intra-observador das aferições volumétricas. Métodos: realizou-se um estudo prospectivo longitudinal envolvendo 52 gestantes normais incluídas entre a $20^{\mathrm{a}}$ e a $32^{\mathrm{a}}$ semanas completas. As medidas do volume do cerebelo fetal foram realizadas com intervalos de duas semanas, utilizando-se o programa VOCAL ${ }^{\mathrm{TM}}$ (Virtual Organ Computeraided Analysis) com ângulo de rotação de $30^{\circ}$. Foram estabelecidos padrões de normalidade do volume cerebelar fetal entre os percentis 10 e 90 para cada idade gestacional estudada, utilizando-se para isso o cálculo da média, desvio-padrão e intervalo de 95\% de confiança. Para avaliar a correlação do volume do cerebelo fetal com a idade gestacional e com os parâmetros do crescimento fetal (circunferência craniana, diâmetro biparietal, diâmetro transverso do cerebelo, comprimento do úmero, comprimento do fêmur, circunferência abdominal e estimativa de peso fetal), utilizou-se o coeficiente de correlação de Pearson (r). Rea- lizou-se análise de regressão polinomial utilizando o volume do cerebelo fetal como variável dependente e os outros parâmetros como variáveis independentes. Testou-se ainda a variabilidade intra-observador nas aferições volumétricas do volume do cerebelo fetal, utilizando-se o coeficiente de correlação intraclasse (p*), o coeficiente de variação e o teste $t$ de Student pareado. Resultados: o volume do cerebelo fetal variou de $1,14 \mathrm{~mL}$ (20 ${ }^{\mathrm{a}}$ semana) à $10,95 \mathrm{~mL}$ (32 ${ }^{\mathrm{a}}$ semana). $\mathrm{O}$ volume do cerebelo fetal foi altamente correlacionado com a idade gestacional $(\mathrm{r}=0,94, \mathrm{p}<0,001)$ e com todos os parâmetros do crescimento fetal $(\mathrm{p}<0.001)$. A variabilidade intra-observador foi excelente $\left(\mathrm{p}^{*}=\right.$ 0,208). Conclusão: o volume do cerebelo fetal é um novo parâmetro de avaliação do crescimento fetal e detecção de anomalias cerebelares, podendo ser utilizado nos casos de suspeita de restrição do crescimento intra-uterino.

PALAVRAS-CHAVE: Ultra-sonografia tridimensional; Feto: crescimento; Cerebelo; Restrição do crescimento intra-uterino

Resumo de Tese

\section{Estudo do polimorfismo de p53 no códon 72 em pacientes com câncer de mama}

\section{Study of p53 codon 72 polymorphism in patients with breast cancer}

Autora: Jussane Oliveira Vieira

Orientador: Prof. Dr. Luiz Henrique Gebrim

Co-orientador: Prof. Dr. Ismael Dale C. G. da Silva

Dissertação de mestrado apresentada à Disciplina de Mastologia do Departamento de Ginecologia da Universidade Federal de São Paulo (UNIFESP-EPM), em 12 de dezembro de 2005.

Introdução: o câncer de mama é uma doença comum nas sociedades ocidentais. O gene supressor de tumor TP53 é um dos mais estudados com relação à presença de mutações. Cerca de 50\% dos tumores apresentam mutações de TP53. O gene TP53 é polimórfico no nucleotídeo 347 (códon 72) e este polimorfismo associa-se a risco de câncer de mama. Objetivo: verificar a associação entre o polimorfismo de TP53 no códon 72 com parâmetros clínico-patológicos de pacientes com câncer de mama. Métodos: foi realizado um estudo do tipo corte transversal incluindo 113 pacientes, submetidas à cirurgia por carcinoma de mama na Disciplina de Mastologia da UNIFESP-EPM, no período de 1999 a 2004. A região polimórfica de TP53 foi submetida à amplificação do DNA genômico, obtido de células bucais, por PCR. Primers específicos obtidos para os alelos pro e arg foram usados. Relacionou-se o polimorfismo com a idade, estadiamento, grau nuclear, comprometimento linfonodal,estado dos receptores hormonais, superexpressão de Her2 e invasão angiolinfática, baseados em dados obtidos retrospectivamente do prontuário. A análise estatística foi realizada pelo teste exato de Fisher. Resultados: o estudo confirmou a maior freqüência do genótipo arg/arg, semelhante à incidência na Grécia e no Japão. A freqüência de p53 arg/arg foi $54 \%$ e em $42,5 \%$ dos casos arg/pro. Não existiu relação entre o polimorfismo e os parâmetros clínico-patológicos. Conclusão: O polimorfismo de TP53, no resíduo 347, não está associado aos achados clínico-patológicos avaliados em pacientes com carcinoma de mama.

PALAVRAS-CHAVE: Câncer de mama; Polimorfismo genético; Gene p53; C-erb-B2. 